\title{
Official Stories
}


Stanford Studies in Middle Eastern and Islamic Societies and Cultures 


\section{Official Stories}

POLITICS AND NATIONAL NARRATIVES

IN EGYPT AND ALGERIA

Laurie A. Brand 
Stanford University Press

Stanford, California

(C)2014 by the Board of Trustees of the Leland Stanford Junior University. All rights reserved.

No part of this book may be reproduced or transmitted in any form or by any means, electronic or mechanical, including photocopying and recording, or in any information storage or retrieval system without the prior written permission of Stanford University Press.

Printed in the United States of America on acid-free, archival-quality paper

Library of Congress Cataloging-in-Publication Data

Brand, Laurie A., author.

Official stories : politics and national narratives in Egypt and Algeria / Laurie A. Brand. pages $\mathrm{cm}$ - (Stanford studies in Middle Eastern and Islamic societies and cultures) Includes bibliographical references and index.

ISBN 978-0-8047-8960-8 (cloth : alk. paper) — ISBN 978-0-8047-9216-5 (pbk. : alk. paper)

1. Egypt—Politics and government-1952-1970. 2. Egypt—Politics and

government-1970-1981.3. Egypt-Politics and government-1981- 4. Algeria-Politics and government-1962-1990.5. Algeria—Politics and government-1990- 6. PropagandaAfrica, North—History—Case studies. 7. Authoritarianism-Africa, North—History—Case studies. I. Title. II. Series: Stanford studies in Middle Eastern and Islamic societies and cultures.

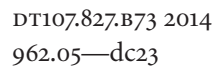

Typeset by Bruce Lundquist in 10/14 Minion 